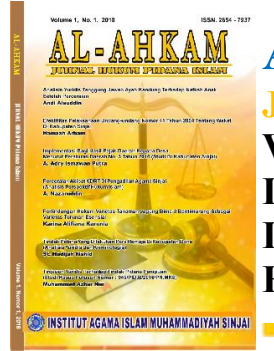

\title{
UPAYA UNIT PPA POLRES POHUWATO DALAM MENANGANI KASUS KEKERASAN TERHADAP PEREMPUAN DALAM RUMAH TANGGA
}

\author{
Herlina Sulaiman', Jelita C. Gress ${ }^{2}$ \\ ${ }^{1}$ Universitas Pohuwato, Jl. Trans Sulawesi No. 147 Marisa \\ ${ }^{2}$ Kepolisian Resor Pohuwato, Jl. Trans Sulawesi No. 147 Marisa \\ E-mail:herlina.sulaiman.hs@gmail.com Tlp.085396098540
}

\begin{abstract}
Abstrak
Kekerasan terhadap perempuan dalam rumah tangga kerap menghiasi wajah penegakan hukum di wilayah Kabupaten Pohuwato. sebagai insan yang dianggap lemah perlunya perelindungan terhadap perrempuan. Untuk itulah Unit PPA Polres Pohuwato hair untuk mendampingi dan menegakkan hukum. Dalam penelitian ini akan menganalisis lebih jauh tentang upaya Unit PPA Polres Pohuwato dalam menangani kasus kekerasan terhadap perempuan dalam rumah tangga, dan untuk mengetahui faktor - faktor pnyebabnya. Penelitian ini menggunakan metode penelitian hukum empiris. Hasil dalam penelitian ini adalah (1) upaya yang dilakukan oleh UPPA Polres Pohuwato dalam menangani kasus kekerasan terhadap perempuan dalam rumah tangga yaitu: Tindakan awal yang dilakukan UPPA Polres Pohuwato saat ada aduan atau laporan kasus KDRT yakni membuat aduan atau Laporan Polisi, menyerahkan Surat Tanda Terima Laporan Polisi, membuat Visum Et Repertum, Melakukaan Pemeriksaan Awal. Melakukan pemeriksaan dalam RPK, UPPA Polres Pohuwato menyediakan Pekerja Sosial (Peksos), Menyediakan pemeriksaan kesehatan dalam hal ini korban KDRT dilakukan pemeriksaan oleh Tim Medis apabila terjadi kekerasan secara fisik, Mengembangkan kerja sama dengan P2TP2A (2) Faktorfaktor yang menjadi penyebab terjadinya kasus kekerasan terhadap perempuan dalam rumah tangga: Faktor Internal dan eksternal.
\end{abstract}

Kata Kunci : Kekerasan, Perempuan,Rumah Tangga.

\begin{abstract}
Violence against women in the household often adorns the face of law enforcement in the Pohuwato Regency. as a human being who is considered weak needs protection from women. For this reason, Pohuwato District Police PPA Unit to assist and enforce the law. In this study, we will further analyze the efforts of the Pohuwato PPA Unit in handling cases of violence against women in the household, and to find out the causes. This research uses empirical legal research methods. The results in this study are (1) the efforts made by UPPA Pohuwato Regional Police in handling cases of violence against women in the household, namely: Initial actions taken by UPPA Pohuwato Regional Police when there were complaints or reports of domestic violence cases, namely making complaints or Police Reports, submitting a Letter of Sign Receive Police Report, make Visum Et Repertum, Conduct Initial Inspection. Conduct examination in the RPK, UPPA Pohuwato Regional Police provide Social Workers (Social Workers), Provide medical examinations in this case victims of domestic violence are examined by the Medical Team in the event of physical violence, Develop cooperation with P2TP2A (2) Factors - factors that cause the occurrence of cases violence against women in the household: Internal and external factors.
\end{abstract}

Keywords: Violence, Women, Household.

\section{Pendahuluan}

Tindak kekerasan dapat terjadi di dalam rumah tangga dan dapat menimpa siapa saja. Bentuk-bentuk kekerasan tersebut dapat secara fisik (kekerasan langsung), kekerasan 


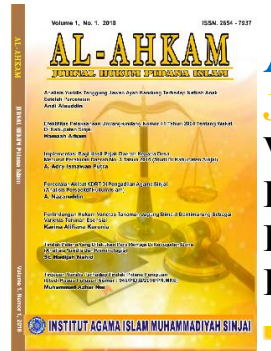

Al-Ahkam

Jurnal Hukum Pidana Islam

Volume 2, No. 1, 2020

ISSN (print) : 2654-7937

ISSN (online) : 2715-0313

Homepage : http://journal.iaimsinjai.ac.id/index.php/al-ahkam/index

struktural, maupun kekerasan kultural. Demikian juga dengan pelaku tindak kekerasan dalam rumah tangga itu. Biasanya, pelaku berasal dari orang-orang terdekat yang dikenal secara baik, seperti suami/istri atau saudara dekat. Bahkan, seorang kakek pun bisa saja menjadi pelaku tindak pidana kekerasan dalam keluarga. Tindakan kekerasan ini merupakan pelanggaran hak asasi manusia dan merupakan kejahatan terhadap martabat kemanusiaan serta bentuk diskriminasi yang harus dihapuskan.

Keutuhan dan kerukunan rumah tangga dapat terganggu jika kualitas pengendalian diri anggota keluarga tidak baik. Dalam kenyataannya tidak sedikit pasangan suami istri yang gagal mencapai tujuan perkawinan, karena hubungannya diliputi tindakan kekerasan, penganiayaan dan penyiksaan sehingga timbul ketidakamanan atau ketidakadilan terhadap orang yang berada dalam rumah tangga tersebut. Dalam kehidupan sehari hari banyak ditemukan perkawinan yang tidak dapat berjalan mulus seperti yang diharapkan, banyak rumah tangga yang seharusnya dapat memberikan kebahagiaan kepada tiap anggotanya berakhir dengan perceraian karena perkawinan tersebut diliputi oleh tindakan Kekerasan Dalam Rumah Tangga (KDRT) yang korbannya banyak dialami oleh para istri dan anak.

Pengertian KDRT itu sendiri menurut Pasal 1 Undang-undang No. 23 Tahun 2004 tentang Penghapusan Kekerasan Dalam Rumah Tangga adalah :

"Perbuatan terhadap seseorang terutama perempuan, yang berakibat timbulnya penderitaan fisik, seksual, psikologis, penelantaran rumah tangga, ancaman, pemaksaan, atau perampasan kemerdekaan secara melawan hukum dalam rumah tangga"

Dalam Pasal 5 UU No. 23 Tahun 2004 menyebutkan "Setiap orang dilarang melakukan kekerasan dalam rumah tangga terhadap orang dalam lingkup rumah tangganya, dengan cara:

a. Kekerasan fisik

b. Kekerasan psikis

c. Kekerasan seksual; atau

d. Penelantaran rumah tangga.

Yang dimaksud dengan macam-macam kekerasan yang disebutkan dalam Pasal 5 tersebut diatas, dipaparkan lebih jelas lagi dalam Pasal - pasal selanjutnya dalam UU No 23 Tahun 2004 tentang Penghapusan Kekerasan Dalam Rumah Tangga sebagai berikut: Kekerasan fisik dijelaskan pada Pasal 6 adalah "Perbuatan yang mengakibatkan rasa sakit, jatuh sakit, atau luka berat". Kekerasan psikis dijelaskan pada Pasal 7 adalah "Perbuatan yang mengakibatkan ketakutan, hilangnya rasa percaya diri, hilangnya kemampuan untuk bertindak, rasa tidak berdaya, dan/atau penderitaan psikis berat pada seseorang".

Kekerasan seksual dijelaskan pada Pasal 8 adalah "Perbuatan yang merupakan pemaksaan seksual yang dilakukan terhadap orang yang menetap dalam lingkup rumah tangga tersebut" dan "Pemaksaan hubungan seksual terhadap salah seorang dalam lingkup rumah tangganya dengan orang lain untuk tujuan komersial dan/atau tujuan tertentu", sedangkan penelantaran rumah tangga dijelaskan pada Pasal 9 dapat diambil kesimpulan bahwa yang dimaksud jenis kekerasan ini berupa "Perbuatan seseorang dimana ia menelantarkan orang yang berada dalam lingkup rumah tangganya, padahal menurut hukum yang berlaku baginya atau karena persetujuan atau perjajian ia wajib memberikan kehidupan, perawatan, pemeliharaan kepada orang tersebut" dan "Bagi orang yang mengakibatkan ketergantungan ekonomi dengan cara membatasi dan/atau melarang untuk bekerja yang layak di dalam atau di luar rumah sehingga korban berada dibawah kendali orang tersebut" dapat juga dikategorikan dalam penelantaran rumah tangga.

Pada dasarnya, kasus kekerasan terhadap perempuan bersumber pada ketimpangan relasi kekuasaan antara perempuan dan laki-laki. Ketimpangan ini disebabkan adanya nilai- 


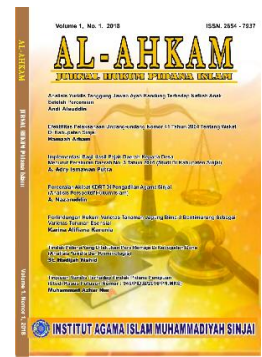

Al-Ahkam

Jurnal Hukum Pidana Islam

Volume 2, No. 1, 2020

ISSN (print) : 2654-7937

ISSN (online) : 2715-0313

Homepage : http://journal.iaimsinjai.ac.id/index.php/al-ahkam/index

nilai patriarki yang membentuk pandangan mengenai laki-laki dan perempuan. Sampai sekarang secara umum masyarakat beranggapan laki-laki mempunyai sifat-sifat berani, tegas, kuat secara fisik, berwibawa serta berani bertindak. Dengan sifat-sifat ini laki-laki dianggap sebagai pencari nafkah, kepala keluarga yang memutuskan seluruh persoalan dalam rumah tangga, sehingga menempatkan laki-laki dalam posisi lebih tinggi dari perempuan. Keadaan ini dapat mengakibatkan timbulnya kekerasan dalam rumah tangga (KDRT) karena adanya ketimpangan relasi, dan juga dapat melanggengkan kekerasan dalam rumah tangga dengan korban perempuan (isteri). Laki- lakipun disosialisasikan untuk melihat perempuan sebagai obyek pelengkap, pihak yang perlu dilindungi, dapat diperlakukan semena-mena, dan adanya kenyataan yang dilengkapi oleh pandangan masyarakat tentang ciri-ciri pada perempuan untuk bersikap pasrah, mengasuh anakanaknya, mendahulukan kepentingan orang lain /suami, mempertahankan ketergantungannya pada laki - laki serta untuk mengutamakan peran sebagai pendamping suami.

Perempuan dari semua kelompok sosial bisa menjadi korban kekerasan dalam rumah tangga. Pengalaman dalam mendampingi perempuan korban kekerasan dan memantau persoalan ini membuat kami menyimpulkan bahwa: perempuan dari semua golongan suku/ bangsa, budaya, agama, tua atau muda, kaya atau miskin, bisa mengalami perlakuan kejam. (Kalyanamitra, $1999: 13$ )

Kekerasan dalam rumah tangga sendiri bukanlah merupakan hal yang sepele, dikarenakan KDRT sendiri dapat menyebabkan beberapa pihak dirugikan baik secara materiil maupun secara immaterial seperti kebutuhan untuk dinafkahi, pendidikan anak, kebutuhan sandang, pangan dan papan merupakan bentuk kebutuhan materiil. Sedangkan kebutuhan imateriil biasanya berbentuk seperti kasih sayang, perhatian dan kebutuhan psikologis. Kenapa hal ini menjadi permasalahan dikarenakan menurut teori -teori relatif atau tujuan sendiri tidaklah cukup adanya suatu kejahatan, tetapi harus dipersoalkan perlu dan manfaatnya suatu pidana bagi masyarakat atau bagi si pelaku sendiri. Tidaklah saja dilihat pada masa lampau, tetapi juga pada masa depan. (Wirjono Prodjodikoro, 2003:25)

Dalam rangka penanganan terhadap kekerasan terhadap perempuan dalam rumah tangga maka perlunya Peran unit Ruang Pelayanan Khusus (RPK). Nama unit Ruang Pelayanan Khusus diganti dengan unit Pelayanan Perempuan dan Anak (PPA) berdasarkan Peraturan Kapolri Nomor Polisi 10 Tahun 2007 tentang Organisasi Dan Tata Kerja Unit Pelayanan Perempuan Dan Anak Di Lingkungan Kepolisian Negara Republik Indonesia.

Unit Pelayanan Perempuan dan anak Polres Pohuwato sebagai salah satu unit yang bergerak di bidang pelayanan bagi korban kekerasan terhadap perempuan dan anak, telah banyak menangani kasus - kasus tentang kekerasan yang terjadi di wilayah Kabupaten Pohuwato. Dalam melaksanakan tugasnya Unit Pelayanan Perempuan dan Anak (UPPA) Polres Pohuwato memiliki tujuan. Tujuan UPPA

a. Memberikan pelayanan dan perlindungan khusus kepada perempuan dan anak yang menjadi saksi, korban, dan /atau tersangka yang ditangani di UPPA.

b. Untuk kepentingan pemeriksaan terhadap saksi dan /atau korban perempuan dan anak serta tindak pidana lainnya.

c. Untuk menghindari terjadinya pelanggaran hak asasi manusia (HAM) dan tindakan yang dapat menimbulkan ekses trauma atau penderitaan yang lebih serius bagi perempuan dan anak.

Berdasarkan uraian latar belakang di atas maka penulis tertarik untuk melakukan pengkajian lebih jauh terhadap “ Upaya Unit Pelayanan Perempuan Dan Anak (Uppa) Dalam Menangani Kasus Kekerasan Terhadap Perempuan Dalam Rumah Tangga (Studi Di Polres Pohuwato)" 


\section{Metode Penelitian}

\section{Jenis Penelitian}

Jenis penelitian yang dipergunakan dalam penelitian ini adalah jenis penelitian yuridis empiris, penelitian ini membahas mengenai permasalahan yang ada berdasarkan peraturan hukum yang berlaku kemudian dikaitkan dengan fakta-fakta atau fenomenafenomena dan dikaitkan dengan suatu pembahasan, dimana penelitian ini mengaitkan antara peraturan hukum yang berlaku dengan keadaan yang terjadi sebenarnya, penelitian hukum empiris ini tidak hanya tertuju pada warga masyarakat tetapi juga kepada penegak hukum dan fasilitas yang diharapkan menunjang pelaksanaan peraturan tersebut. (Bambang Waluyo, 2002:10)

\section{Objek Penelitian}

Objek di dalam penelitian ini adalah mengenai peranan Unit Pelayanan Perempuan dan Anak (UPPA) Polres Pohuwato dalam menangani perkara kekerasan terhadap perempuan dalam rumah tangga yang terjadi di wilayah hukum Polres Pohuwato.

\section{Waktu dan Lokasi Penelitian}

Penelitian ini dilaksanakan dari bulan Juni 2018 sampai dengan Januari 2019 di Kepolisian Resor Pohuwato khususnya pada Unit Pelayanan Perempuan dan Anak

\section{Teknik Pengumpulan Data}

1. Data Primer

Pengumpulan data primer dilakukan dengan cara wawancara (interview) dengan narasumber berdasarkan pokok-pokok pertanyaan yang berkaitan langsung dengan permasalahan dalam penelitian ini.

2. Data Sekunder.

a) Data Kepustakaan ( Library Reasearch)

Pengumpulan data akan dilakukan dengan mengadakan pengumpulan, pengkajian dan pengolahan secara sistematis terhadap literatur peraturan perundang-undangan maupun karangan ilmiah sebagai penunjang teori dalam penulisan serta pembahasan hasil penelitian.

b) Studi Dokumen

Dilakukan dengan memahami data-data yang berkaitan langsung dengan judul penelitian.

\section{Analisis Data}

Data-data yang telah diperoleh, baik itu data primer maupun data sekunder, selanjutnya dianalisis dan diolah dengan metode case study (studi kasus). Dimana data primer kemudian dibahas kaitannya dengan berbagai data sekunder untuk menghasilkan suatu kesimpulan terkait masalah yang diteliti.

\section{Hasil Dan Pembahasan}

\section{Upaya Yang Dilakukan Oleh Unit Pelayanan Perempuan Dan Anak Polres Pohuwato Dalam Menangani Kasus Kekerasan Terhadap Perempuan Dalam Rumah Tangga Di Wilayah Hukum Polres Pohuwato.}

Istilah kekerasan digunakan untuk menggambarkan perilaku, baik yang terbuka (overt), tertutup (covert), dan baik yang bersifat menyerang (offensive) atau bertahan (deffensive), yang disertai penggunaan kekuatan kepada orang lain. (Thomas Santoso, 2002:11). Rita Serena Kalibonso (2000:8) mempunyai pendapat mengenai bentuk-bentuk kekerasan, yaitu: 


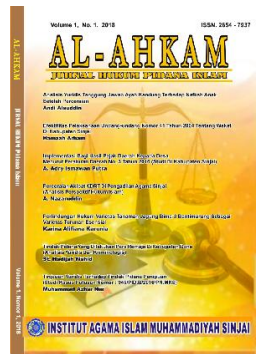

Al-Ahkam

Jurnal Hukum Pidana Islam

Volume 2, No. 1, 2020

ISSN (print) : 2654-7937

ISSN (online) : 2715-0313

Homepage : http://journal.iaimsinjai.ac.id/index.php/al-ahkam/index

a. Kekerasan fisik, adalah setiap perbuatan yang menyebabkan rasa sakit pada tubuh seseorang dan/atau menyebabkan kematian.

b. Kekerasan psikologis, adalah tiap-tiap perbuatan dan ucapan yang mengakibatkan ketakutan, hilangnya rasa percaya diri, hilangnya kemampuan untuk bertindak dan rasa tidak berdaya pada seseorang.

c. Kekerasan seksual, adalah tiap-tiap perbuatan yang mencakup pelecehan seksual sampai pada memaksa seseorang untuk melakukan perbutan seksual tanpa persetujuan korban atau disaat korban tidak menghendaki dan/atau melakukan hubungan seksual dengan cara-cara tidak wajar atau tidak disukai korban; dan atau menjauhkan (mengisolasi) dari kebutuhan seksualnya.

d. Kekerasan ekonomi, adalah tiap-tiap perbuatan yang membatasi seseorang untuk bekerja di dalam atau di luar rumah yang menghasilkan uang dan/atau barang; dan atau membiarkan korban bekerja untuk dieksploitasi atau menelantarkan keluarga.

e. Perampasan kemerdekaan secara sewenang-wenang, adalah semua perbuatan yang menyebabkan terisolirnya seseorang dari lingkungan sosialnya (diantaranya larangan keluar rumah atau larangan berkomunikasi dengan orang lain)

Kekerasan dalam rumah tangga sebagai kekerasan domestik merupakan suatu fenomena dalam lingkungan masyarakat yang sampai saat ini dan masa yang akan datang kemungkinan besar akan terus terjadi. Anne Grant dalam Karyanya Breaking The Cycleof Violence mendefisinsikan kekerasan domestk sebagai pola perilaku menyimpang (assaultive) dan memaksa (Corsive), termasuk serangan secara fisik, seksual, psikologis, dan pemaksaan secara ekonomi yang dilakukan oleh orang dewasa kepada pasangan intimnya. (Achmad Chusairi, 2000:109)

Hasbianto menyatakan bahwa kekerasan dalam rumah tangga adalah suatu bentuk penganiayaan (abuse) secara fisik maupun emosional/psikologis, yang merupakan suatu cara pengontrolan terhadap pasangan dalam kehidupan rumah tangga, dan membagi kekerasan dalam rumah tangga menjadi 4 jenis yakni kekerasan seksual, kekerasan fisik, kekerasan ekonomi dan kekerasan emosional. (Sri Meiyenti, 1999:6)

Umumnya, kekerasan dalam rumah tangga terjadi apabila ada penyalahgunaan kekerasan oleh mereka yang memiliki kekuasaan lebih. Yang dimaksud dengan pihak yang memiliki kekuasaan lebih adalah orang-orang yang secara kultural, memiliki posisi yang dominan di banding yang lain di dalam keluarga, contohnya adalah suami terhadap istri dan anak-anaknya.

Laki-laki di dalam konstruksi sosial masyarakat Indonesia memang dimitoskan sebagai sosok yang memiliki kemampuan dan kekuatan lebih dibandingkan perempuan. Hal tersebut membuat kedudukan laki-laki di mata masyarakat lebih tinggi (dominan) dibandingkan perempuan.Konstruksi sosial yang timpang terhadap posisi laki-laki dan perempuan, semakin jelas terlihat di dalam keluarga, dimana laki-laki (suami) merupakan kepala keluarga yang berhak mengambil setiap keputusan di dalam keluarga (decision maker) bahkan paham tersebut dilegitimasi oleh hukum, seperti yang dinyatakan di dalam Undang-undang Perkawinan No.1 Tahun 1974 di dalam Pasal 31 ayat (3) dinyatakan bahwa, "Suami adalah kepala keluarga dan istri adalah ibu rumah tangga".

Untuk memaksimalkan peran Pemerintah dalam mencegah maupun menangani kekerasan dalam rumah tangga telah dikeluarkan berbagai macam peraturan baik dalam bentuk undang - undang maupun peraturan peraturan di bawahnya.

Dalam UU No. 23 Tahun 2004 yang dimaksud dalam anggota rumah tangga diatur dalam Pasal 2 yang menyatakan :

(1) Lingkup rumah tangga dalam Undang-Undang ini meliputi : 


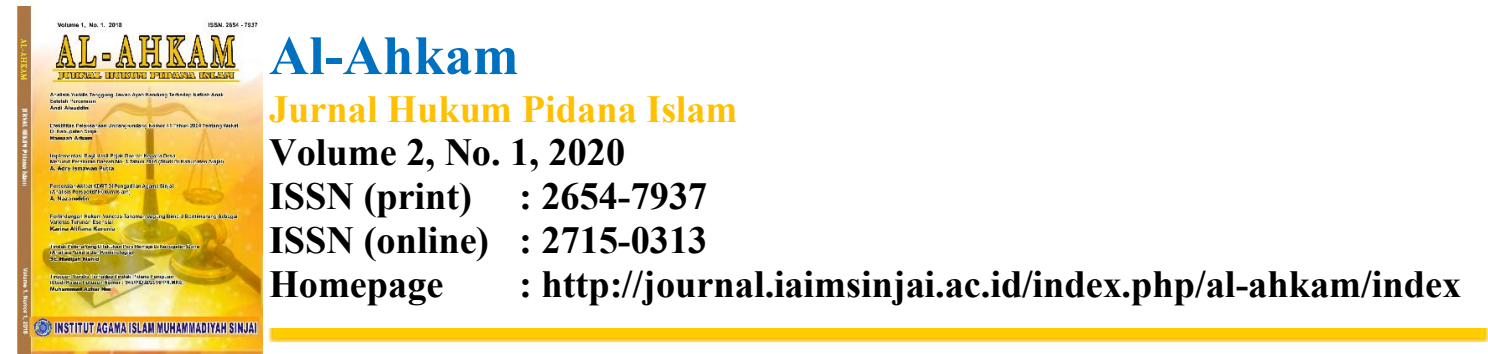

a. suami, isteri, dan anak;

b. orang-orang yang mempunyai hubungan keluarga dengan orang sebagaimana dimaksud pada huruf a karena hubungan darah, perkawinan, persusuan, pengasuhan, dan perwalian, yang menetap dalam rumah tangga; dan/atau

c. orang yang bekerja membantu rumah tangga dan menetap dalam rumah tangga tersebut.

(2) Orang yang bekerja sebagaimana dimaksud pada huruf c dipandang sebagai anggota keluarga dalam jangka waktu selama berada dalam rumah tangga yang bersangkutan.

Mengenai pengertian kekerasan dalam rumah tangga telah jelas diatur dalam Pasal 1 Butir 1 UU No 23 Tahun 2004 diatur bahwa :

"Kekerasan dalam Rumah Tangga adalah setiap perbuatan terhadap seseorang terutama perempuan, yang berakibat timbulnya kesengsaraan atau penderitaan secara fisik, seksual, psikologis, dan/atau penelantaran rumah tangga termasuk ancaman untuk melakukan perbuatan, pemaksaan, atau perampasan kemerdekaan secara melawan hukum dalam Iingkup rumah tangga."

Bentuk-bentuk Kekerasan dalam rumah Tangga adalah meliputi

1. Kekerasan fisik, yaitu setiap perbuatan yang mengakibatkan rasa sakit, luka fisik, cedera, pingsan, cacat permanen, gugurnya kandungan dan atau sampai mengakibatkan kematian

2. Kekerasan psikis, yaitu setiap perbuatan yang mengakibatkan ketakutan, hilangnya rasa percaya diri, hilangnya kemampuan untuk bertindak, rasa tidak berdaya, penderitaan dan atau gangguan psikis berat pada seseorang.

3. Kekerasan seksual, yaitu setiap perbuatan yang ditujukan terhadap tubuh atau seksualitas seseorang untuk tujuan merendahkan martabat serta integritas tubuh atau seksualitasnya, yang berdampak secara fisik maupun psikis.

4. Kekerasan ekonomi, yaitu setiap perbuatan yang mengakibatkan kerugian secara ekonomi dan terlantarnya anggota keluarga dan atau menciptakan ketergantungan ekonomi dengan cara membatasi dan atau melarang untuk bekerja di dalam atau di luar rumah, tidak memberikan nafkah, meniadakan akses, control serta partisipasi berkenaan dengan sumber-sumber ekonomi dan menelantarkan anggota keluarga.

Penanganan KDRT dalam lingkup wilayah hukum Polres Pohuwato ditangani langsung oleh Unit Pelayanan Perempuan dan Anak Polres Pohuwato. Keberadaan Unit PPA menjadi suatu solusi utama yang dapat langsung dirasakan manfaatnya oleh masyarakat khususnya perempuan dan anak. Perlu diketahui bahwa dasar dari pembentukan UPPA adalah dikeluarkannya Peraturan Kapolri Nomor 10 Tahun 2007 tanggal 6 Juli 2007 tentang Pembentukan Unit Pelayanan Perempuan dan Anak (UPPA) pada lingkungan Kepolisian Negara Republik Indonesia. Unit Pelayanan Perempuan dan Anak (UPPA) merupakan unit yang bertugas memberikan pelayanan dalam bentuk perlindungan terhadap perempuan dan anak yang menjadi korban kejahatan dan penegakan hokum terhadap pelakunya, ( termasuk perempuan dan anak yang menjadi pelaku tindak pidana ). Saat ini personel yang tergabung di dalam Unit PPA Polres Pohuwato sejumlah 6 (enam orang) yang dapat dilihat di dalam Tabel berikut:

Tabel 1. Data Anggota Unit PPA Polres Pohuwato

\begin{tabular}{|c|c|c|}
\hline No & Nama & Jabatan \\
\hline 1 & Amzai, S.E & Kanit UPPA \\
\hline
\end{tabular}




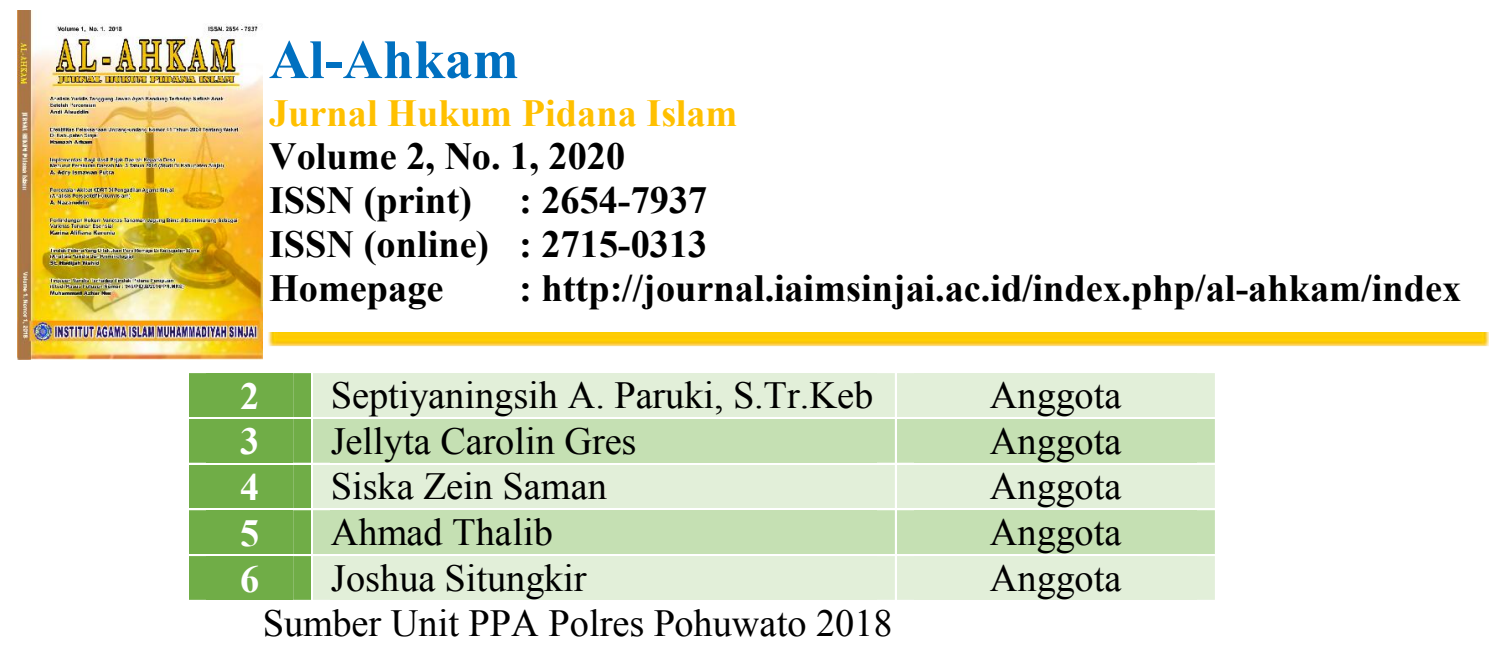

Sejak berdirinya UPPA di Polres Pohuwato telah banyak menangani kasus KDRT. Hal tersebut dibuktikan dengan data yang penulis dapat dari Unit Pelayanaan Perempuan dan Anak Kepolisian Resor Pohuwato yang mana dapat dilihat dari tabel berikut :

Tabel 2. Data Kasus Kekerasan Dalam Rumah Tangga (KDRT) Perempuan Sebagai Korban Tahun 2013 - 2015

\begin{tabular}{|l|l|c|}
\hline No & Tahun & Kasus kekerasan \\
\hline $\mathbf{1}$ & 2013 & 11 \\
\hline $\mathbf{2}$ & 2014 & 19 \\
\hline $\mathbf{3}$ & 2015 & 9 \\
\hline
\end{tabular}

Sumber UPPA Polres Pohuwato 2018

Berdasarkan data per tiga tahun diatas dapat diketahui bahwa pada tahun 2013 terjadi 11 Kasus, 2014 sebanyak 19 kasus dan 2015 sebanyak 9 kasus. Kemudian untuk 3 tahun berikutnya yaitu tahun $2016-2018$ dapat dilihat pada tabel berikut :

Tabel 3. Data Kasus Kekerasan Dalam Rumah Tangga (KDRT) Perempuan Sebagai Korban Tahun 2016 - Januari 2018

\begin{tabular}{|l|c|c|c|}
\hline \multicolumn{1}{|c|}{ Kasus Kdrt } & 2016 & 2017 & 2018 \\
\hline Fisik & 13 & 8 & 1 \\
\hline Psikis & - & - & - \\
\hline Seksual & - & - & - \\
\hline Penelantaran & - & - & - \\
\hline Jumlah & 13 & 8 & 1 \\
\hline
\end{tabular}

Sumber : UPPA Polres Pohuwato 2018

Berdasarkan data di atas dapat diketahui bahwa kekerasan tehadap perempuan dalam rumah tangga di Kabupaten Pohuwato sejak tahun 2016 sampai dengan 2018 di dominasi oleh kekerasan terhadap fisik. Pada tahun 2016 terjadi 13 kasus, 20178 kasus dan 2018 sampai dengan bulan September terjadi 1 kasus. Dalam kurun waktu 6 tahun terakhir kasus terbanyak yaitu pada tahun 2014 sebanyak 19 kasus.

Menurut Bapak Ahmad Thalib (wawancara tanggal 24 Oktober 2018) Anggota Unit Pelayanan Perempuan dan Anak, bahwa kasus kekerasan dalam rumah tangga merupakan salah satu hidden crime atau kekerasan yang terselubung karna masih banyaknya kasus yang tidak dilaporkan oleh korban maupun pihak-pihak yang yang memiliki kuasa untuk melakukan pelaporan.

Adanya non-reporting ini disebabkan oleh berbagai hal, antara lain: 


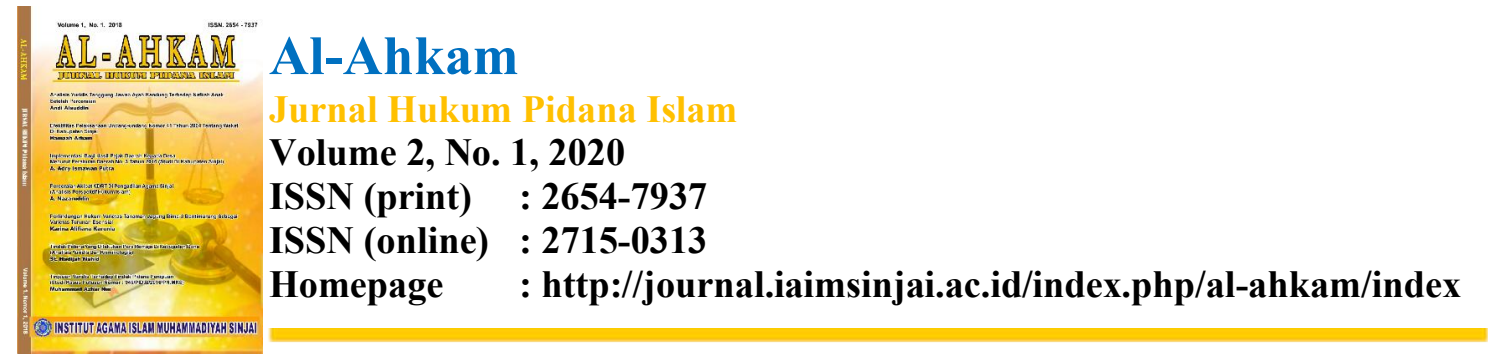

1. si korban malu karena peristiwa ini telah mencemarkan dirinya, baik secara fisik, psikologi maupun sosiologis;

2. si korban merasa berkewajiban melindungi nama baik keluarganya, terutama jika pelaku adalah anggota keluarga sendiri;

3. si korban merasa bahwa proses peradilan pidana terhadap kasus ini belum tentu dapat membuat dipidananya si pelaku;

4. si korban khawatir bahwa diprosesnya kasus ini akan membawa cemar yang lebih tinggi lagi pada dirinya (misalnya melalui publikasi media massa, atau cara pemeriksaan aparat hukum yang dirasanya membuatnya makin terluka);

5. si korban khawatir akan retaliasi atau pembalasan dari pelaku (terutama jika pelaku adalah orang yang dekat dengan dirinya);

6. lokasi kantor polisi yang jauh dari tempat tinggal korban, membuatnya enggan melapor;

7. keyakinan korban bahwa walaupun ia melapor ia tidak akan mendapat perlindungan khusus dari penegak hukum;

8. ketidaktahuan korban bahwa yang dilakukan terhadap dirinya merupakan bentuk tindak kekerasan terhadap perempuan. (Harkristuti Harkrisnowo Jurnal Hukum Volume 14 Volume 7 Agustus 2000/ Hukum Pidana dan Perspektif Kekerasan terhadap Perempuan Indonesia, https://media.neliti.com/media/publications/83370-none-771195ff.pdf)

Selain dari alasan di atas, adanya anggapan dari kaum perempuan dalam rumah tangga yang masih awam terhadap hak - hak mereka dalam rumah tangga bahwa adanya kekerasan yang diterima oleh mereka dari suaminya adalah merupakan suatu ganjaran yang wajar untuk di dapatkan atas kelalaian atau kesalahan yang diperbuat, ataupun merupakan suatu hal yang biasa Karena adanya anggapan bawa istri wajib menerima segala perlakuan dari suami. korban biasanya lebih cenderung menyimpan masalah karena dianggap sebagai aib keluarga dan tidak pantas diketahui orang lain. Korban juga menganggap pelaku khilaf dan suatu saat akan menyadari kesalahannya. Alasan lainnya, korban masih mencintai pelaku sehingga tidak tega untuk melaporkan permasalahan ke pihak berwenang.

Upaya yang dilakukan Unit Pelayanan Perempuan dan Anak Polres Pohuwato dalam melaksanakan salah satu tugasnya dalam hal perlindungan terhadap korban KDRT khususnya perempuan sebagai korban tentunya melibatkan beberapa pihak seperti P2TP2A (Pusat Pelayanan Terpadu Perlindungan Perempuan dan Anak) Kabupaten Pohuwato, dan Pekerja Sosial.

UPPA Polres Pohuwato dalam menangani korban kekerasan KDR khususnya perempuan wajib memperhatikan hak-hak korban sesuai amanat UU No 23 Tahun 2004. Hak - hak tersebut diatur dalam pasal 10:

Korban berhak mendapatkan :

a. Perlindungan dari pihak keluarga, kepolisian, kejaksaan, pengadilan, advokat, lembaga social, atau pihak lainnya baik sementara maupun berdasarkan penetapan perintah perlindungan dari pengadilan;

b. Pelayanan keseatan sesuai dengan kebutuhan medis;

c. Penanganan secara khusus berkaitan dengan kerahasiaan korban;

d. Pendampingan oleh pekerja social dan bantuan hukum pada setiap tingkat proses pemeriksaan sesuai dengan ketentuan peraturan perundang-undangan; dan

e. Pelayanan bimbingan rohani. 


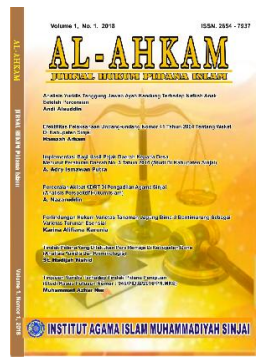

Upaya Unit Pelayanan Perempuan dan anak dalam penanganan tindak pidana KDRT tentunya diawali dari adanya laporan dari pihak korban. Karena perlunya diketahui bahwa KDRT sebagai domestic violence termasuk dalam delik aduan yang absolut sehingga harus adanya laporan langsung dari pihak korban. Hal ini seperti diatur dalam Pasal 51 sampai dengan Pasal 53 UU No 23 Tahun 2004 bahwa Tindak pidana kekerasan fisik, tindak pidana kekerasan psikis dan tindak pidana kekerasan seksual merupakan delik aduan.

Berdasarkan wawancara penulis dengan Anggota Unit UPPA Polres Pohuwato yakni Ibu Septiyaningsih A. Paruki, S.Tr.Keb. (wawancara pada tanggal 8 oktober 2018) menyatakan:

Tindakan yang dilakukan UPPA Polres Pohuwato saat ada aduan atau laporan kasus

KDRT yakni membuat aduan atau Laporan Polisi, menyerahkan Surat Tanda Terima

Laporan Polisi, membuat Visum Et Repertum, Melakukaan Pemeriksaan Awal.

Berdasarkan hasil penelitian penulis tahapan penerimaan laporan polisi adalah sebagai berikut :

a) Korban diterima oleh personel UPPA.

b) Proses Pembuatan Laporan Polisi didahului dengan wawancara dan pengamatan serta penilaian penyidik/petugas terhadap keadaan saksi dan korban

c) Apabila saksi korban dalam kondisi trauma/stres, penyidik melakukan penindakan penyelamatan dengan mengirim saksi korban ke Rumah Sakit untuk mendapatkan penanganan medis - psikis serta memantau perkembangannya.

d) Dalam hal saksi dan/atau korban memerlukan istirahat petugas mengantar ke ruang istirahat atau rumah aman atau shelter.

e) Apabila korban dalam kondisi sehat dan baik, penyidik dapat melaksanakan wawancara guna pembuatan laporan Polisi.

f) Pembuatan laporan Polisi oleh petugas UPPA dan bila perlu mendatangi TKP untuk mencari dan mengumpulkan barang bukti.

g) Register penomoran laporan Polisi ke Sentra Pelayanan Kepolisian (RPK).

h) Dalam hal saksi dan /atau korban perlu dirujuk ke PPT atau tempat lainnya, petugas wajib mengantarkan sampai ketempat tujuan rujukan, dan menyerahkan kepada petugas yang bersangkutan disertai dengan penjelasan masalahnya.

i) Dalam hal saksi/atau korban selesai dibuatkan laporan Polisi dan perlu visum maka petugas mengantarkan saksi dan /atau koraban ke PPT untuk mendapatkan pemeriksaan kesehatan dan visum.

j) Kasus yang tidak memenuhi unsur pidana, dilakukan upaya bantuan melalui konseling dan pendekatan psikologis.

Dalam pelayanan terhadap korban telah ditemtukan Pasal 13 huruf a UU Nomor 23 Tahun 2004 Tentang PKDRT yaitu untuk penyelenggaraan pelayanan terhadap korban, pemerintah dan pemerintah daerah sesuai dengan fungsi dan tugas masing-masing dapat melakukan upaya salah satunya adalah penyediaan ruang pelayanan khusus di kantor kepolisian. Namun apabila korban tidak dapat hadir di UPPA, maka pemeriksaan dapat dilakukan dirumah /kediaman saksi dan/atau korban atau tempat lain yang diinginkan oleh saksi dan /atau korban.

Selain dari beberapa hal yang telah dikemukakan dalam penanganan korban menurut Ibu Septiyaningsih A. Paruki, S.Tr.Keb. (wawancara pada tanggal 8 oktober 2018) bahwa tindakan - tindakan selanjutnya dalam menangani kasus KDRT yakni

- Melakukan pemeriksaan dalam Ruang Pelayanan Khusus (RPK)

- UPPA Polres Pohuwato menyediakan Pekerja Sosial (Peksos)

- Menyediakan pemeriksaan kesehatan dalam hal ini korban KDRT dilakukan pemeriksaan oleh Tim Medis apabila terjadi kekerasan secara fisik 
- Mengembangkan kerja sama dengan P2TP2A

Dalam pelaksanaan pemeriksaan terhadap saksi dan/atau korban pada UPPA Polres Pohuwato dilaksanakan dengan memperhatikan ketentuan sebagai berikut :

a) Petugas tidak memakai pakaian dinas yang dapat berpengaruh psikis saksi dan atau /korban yang akan diperiksa,

b) Menggunakan bahasa yang mudah dimengerti oleh yang diperiksal.

c) Pertanyaan diajukan dengan ramah dan rasa empati.

d) Dilarang memberikan pertanyaan yang dapat menyinggung perasaan atau halhal yang sangat sensitif bagi saksi dan/atau korban yang diperiksa.

e) Tidak melaksanakan pengakuan, atau melaksanakan keterangan dari yang diperiksa.

f) Tidak menyudutkan atau menyalahkan atau mencemooh atau melecehkan yang di periksa.

g) Tidak memberikan pertanyaan yang dapat menimbulkan kekesalan/kemarahan yang diperiksa;

h) Tidak bertindak diskrimatif dalam memberikan pelayanan/pemeriksaan.

i) Selama melakukan pemeriksaan, petugas senantiasa menunjukkan bersahabat, melindungi, mengayomi yang diperiksa;

j) Selama dalam pemeriksaan, petugas mendengarkan dengan saksi dengan keluhan, penjelasan, argumentasi, aspirasi, dan harapan untuk kelengkapan hasil laporan polisi yang berguna bagi proses selanjutnya;

k) Selama dalam pemeriksaan, petugas senantiasa menaruh perhatian terhadap situasi dan kondisi fisik maupun kondisi kejiwaan yang diperiksa;

1) Standar urutan pertanyaan yang diajukan antara lain sebagai berikut :

a. Menanyakan kesehatan serta kesediaannya untuk diperiksa.

b. Menanyakan tentang bahasa yang di pahami dan akan digunakan dalam pemeriksaan.

c. Menanyakan perlu tidaknya didampingi oleh penasehat hukum atau pedamping lainnya.

d. Dalam hal yang diperiksa adalah anak, pemeriksa wajib memperhatikan dan mempedomani peraturan perundang-ndangan yang berkaitan dengan anak.

e. Pemeriksaan terhadap anak wajib disediakan pendamping dan atau penasehat hukum dan/ atau psikolog atau penyidik.

m. Pertanyaan yang diajukan dalam rangka mendapatkan keterangan mengenai subtansi perkara yang sedang diperiksa, antara lain :

1) Latar belakang permasalahan atau perkara.

2) Kronologis peristiwa yang dialami oleh saksi dan/ atau korban.

3) Kerugian yang diderita oleh saksi dan/ atau korban sebagai bahan pengajuan restitusi atau pemberian ganti rugi.

4) Barang bukti yang dapat diperoleh dan dapat digunakan untuk alat bukti.

5) Hubungan saksi dan /atau korban dengan saksi lainnya atau tersangka.

6) Tuntutan atau harapan saksi dan/atau korban.

n. Pertanyaan yang perlu diberikan pada bagian akhir pemeriksaan antara lain :

1) Pembacaan kembali hasil pemeriksaan.

2) Apakah ada jawaban-jawaban sebelumnya, perlu dikoreksi/diubah.

3) Apakah ada keterangan tambahan.

4) Apakah ada pemaksaan dalam memberikan keterangan.

5) Apakah bersedia menandatangani BAP. 


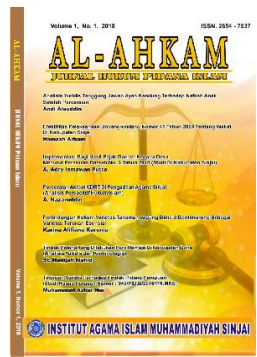

Al-Ahkam

Jurnall Hukum Pidana Islam

Volume 2, No. 1, 2020

ISSN (print) : 2654-7937

ISSN (online) : 2715-0313

Homepage : http://journal.iaimsinjai.ac.id/index.php/al-ahkam/index

Penanganan korban perempuan korban KDRT bukan saja terbatas pada penanganan pada saat terjadi tindak pidana KDRT, namun ada pula rangkaian perlindungan yang wajib diberikan oleh UPPA kepada korban. Menurut Ibu Septiyaningsih A. Paruki, S.Tr.Keb. (wawancara pada tanggal 8 oktober 2018) bahwa Perlindungan hukum yang diberikan oleh UPPA Polres Pohuwato memberikan upaya perlindungan dalam hal rasa aman baik kepada korban sendiri dan saksi dalam proses penyelidikan dan penyidikan di tingkat Kepolisian.

Selanjutnya Ibu Siska Zein Saman (wawancara pada tanggal 24 oktober 2018) yang merupakan anggota UPPA Polres Pohuwato menambahkan bahwa :

"Pemberian perlindungan korban terhadap korban KDRT telah diiatur oleh UU

PKDRT dalam pasal 16. Adapun bentuk-bentuk perlindungan hukum dari pihak polres pohuwato terhadap korban KDRT yakni :

- Dalam waktu 1x24 jam terhitung mengetahui atau menerima laporan KDRT kepolisian memberikan perlindungan sementara

- Dalam waktu 1x24 jam sejak diberikannya perlidungan sementara yang diberikan oleh Kepolisian, kepolisian meminta surat penetapan perintah perlindungan dari Pengadilan

- Dalam memberikan perlindungan sementara Kepolisian bekerjasama dengan instansi yang terkait dengan P2TP2A"

Pada poin kedua diatas telah diatur bahwa kepolisian hanyalah memberikan perlindaungan sementara. Untuk selanjutnya perlindungan dapat dilanjutkan setelah menerima surat perintah dari pengadilan. Ketua pengadilan dalam tenggang waktu 7 (tujuh) hari sejak diterimanya permohonan wajib mengeluarkan surat penetapan yang berisi perintah perlindungan bagi korban dan anggota keluarga lain, kecuali ada alasan yang patut. Untuk mendapatkan surat perintah perlindungan dapat diajukan oleh :

a. korban atau keluarga korban;

b. teman korban;

c. kepolisian;

d. relawan pendamping; atau

e. pembimbing rohani. (pasal 29)

Permohonan perintah perlindungan disampaikan dalam bentuk lisan atau tulisan. Dalam hal permohonan diajukan secara lisan, panitera pengadilan negeri setempat wajib mencatat permohonan tersebut. Dalam hal permohonan perintah perlindungan diajukan oleh keluarga, teman korban, kepolisian, relawan pendamiping, atau pembimbing rohani maka korban harus memberikan persetujuannya. Dalam keadaan tertentu, permohonan dapat diajukan tanpa persetujuan korban.

Penanganan Kasus KDRT tidak selamanya berjalan dengan mudah tanpa kendala. Menurut Ibu Septiyaningsih A. Paruki, S.Tr.Keb. (wawancara pada tanggal 8 oktober 2018) Yang menjadi kendala dalam penanganan kasus KDRT yakni

1. laporan telah diterima oleh Unit PPA namun korban biasanya tidak lagi mengecek laporan tersebut,

2. korban sudah tidak bisa dihubungi,

3. bahkan Tindakan yang dilakukan UPPA Polres Pohuwato saat ada aduan atau laporan kasus KDRT yakni membuat aduan atau Laporan Polisi, menyerahkan Surat Tanda Terima Laporan Polisi, membuat Visum Et Repertum, Melakukaan Pemeriksaan Awal namun korban sudah tidak tinggal di wilayah Pohuwato.

4. Korban masih tergantung secara ekonomi dengan pelaku sehingga mencabut laporannya

5. Keterlambatan korban melapor sehingga bukti fisik sudah hilang. 


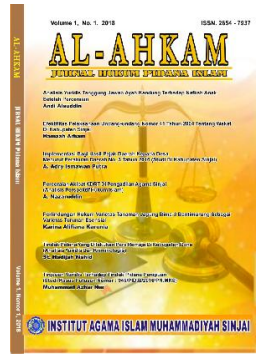

Al-Ahkam

Jurnall Hukum Pidana Islam

Volume 2, No. 1, 2020

ISSN (print) : 2654-7937

ISSN (online) : 2715-0313

Homepage : http://journal.iaimsinjai.ac.id/index.php/al-ahkam/index

6. Kuranngya kooperatif dari keluarga untuk memberikan keterangan Karena menganggap KDRT sebagai aib keluarga.

Faktor - Faktor Yang Menjadi Penyebab Terjadinya Kasus Kekerasan Terhadap Perempuan Dalam Rumah Tangga Di Wilayah Hukum Polres Pohuwato

Dengan dasar dominasi perasaan takut, respon, dan pengalaman psikologis yang sering muncul dari korban kekerasan domestik adalah (Kristi Poewandari, 1999:34):

1. Meminimalkan kejadian kekerasan yang dialami, karena beberapa alasan:

- ketakutannya bahwa membicarakan kekerasan tersebut akan membuatnya berada dalam situasi lebih buruk

- kurangnya informasi akurat mengenai apa yang sesungguhnya terjadi padanya, siapa yang sesungguhnya bermasalah dan menjadi korban

- kebutuhannya untuk menyakini itu tidak seberat yang dibayangkan adalah cara beradaptasi terhadap kekerasan yang dialami sampai ia siap menghadapi realitas dan mampu mengambil tindakan-tindakan pengamanan perasaan malu dan kebingungannya menghadapi kekerasan

- keyakinannya bahwa ia bertanggung jawab atas kejadian tersebut.

2. Terisolasi.

3. Perasaan tidak berdaya.

4. Menyalahkan diri (internalizes blame).

5. Ambivalensi.

6. Harga diri rendah.

7. Harapan.

Kekerasan terhadap perempuan secara khusus digolongkan dalam beberapa hal sebagaimana pendapat Aroma Elmina Martha (2003: 24) sebagai berikut :

1) Kekerasan dalam area domestik/hubungan intim personal. Berbagai bentuk kekerasan yang terjadi di dalam hubungan keluarga, antara pelaku dan korbannya memiliki kedekatan tertentu. Tercakup disini adalah penganiayaan terhadap istri, pacar, bekas istri, tunangan, anak kandung dan anak tiri, penganiayaan terhadap orang tua, serangan seksual atau perkosaan oleh anggota keluarga.

2) Kekerasan dalam area publik. Berbagai bentuk kekerasan yang terjadi di luar hubungan keluarga atau hubungan personal lain, sehingga meliputi berbagai bentuk kekerasaan yang sangat luas, baik yang terjadi di semua lingkungan tempat kerja maupun di tempat umum.

3) Kekerasan yang dilakukan oleh/dalam lingkup negara. Kekerasan secara fisik, seksual dan/atau psikologis yang dilakukan, dibenarkan, didiamkan terjadi oleh negara di mana pun terjadinya. Termasuk dalam kelompok ini adalah pelanggaran hak asasi manusia dalam pertentangan antar kelompok, dan situasi kelompok, dan situasi konflik bersenjata yang terkait dengan pembunuhan, pemerkosaan, perbudakan seksual dan kekerasan paksa.

Pemerintah melalui UU Nomo 23 Tahun 2004 telah berupaya menekan angka kekerasan terhadap perempuan dalam rumah tangga. Penentuan sanksi pidana terhadap pelaku KDRT tergolong sangat tinggi. Bukan hanya hukuman pidana namun ada pula hukuman denda yang wajib dipenuhi oleh si terpidana. Adapun ancaman hukuman terhadap tindak pidana kekerasan dalam rumah tangga yaitu:

a) Kekerasan Fisik :

Setiap orang yang melakukan perbuatan kekerasan fisik dalam lingkup rumah tangga sebagaimana dimaksud dalam pasal 5 yakni kekerasan fisik, dipidana dengan pidana penjara 5 tahun atau denda paling banyak Rp 15.000.000 (lima belas 


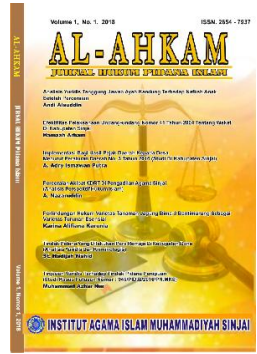

\section{Al-Ahkam}

Jurnall Hukum Pidana Islam

Volume 2, No. 1, 2020

ISSN (print) : 2654-7937

ISSN (online) : 2715-0313

Homepage : http://journal.iaimsinjai.ac.id/index.php/al-ahkam/index

juta rupiah). Apabila korban jatuh sakit atau luka berat maka diancam hukuman penjara 10 tahun penjara atau hukuman denda Rp 30.000.000 (tiga puluh juta rupiah) . Apabila korban meninggal dunia maka pelaku diancam dengan pidana penjara 15 tahun atau hukuman denda Rp 45.000 .000 (empat puluh lima juta rupiah). Hal ini telah diatur secara limitatif dalam pasal 44 UU No 23 tahun 2004.

b) Kekerasan Psikis :

Setiap orang yang melakukan perbuatan kekerasan psikis dalam lingkup rumah tangga, dipidana dengan hukuman penjara paling lama 3 tahun atau hukuman denda paling banyak Rp 9.000.000 (sembilan juta rupiah). Dalam hal perbuatan sebagaimana dimaksud diatas dilakukan suami terhadap istri, atau sebaliknya yang tidak menimbulkan penyakit atau halangan untuk menjalankan pekerjaan, jabatan atau mata pencaharian atau kegiatan sehari-hari, dipidana dengan pidana penjara paling lama 4 (empat) bulan atau denda paling banyak Rp 3.000.000 Tiga juta rupiah (Pasal 45 UU 23 Tahun 2004).

c) Kekerasan Seksual :

Setiap orang yang melakukan perbuatan kekerasan seksual sebagaimana dimaksud dalam pasal 8 huruf a yaitu pemaksaan hubungan seksual yang dilakukan terhadap orang yang menetap dalam lingkup rumah tangga, dipidana penjara paling lama 12 tahun atau denda paling banyak Rp 36.000.000 Tiga puluh enam juta rupiah (pasal 46 UU No 23 Tahun 2004)

d) Penelantaran Rumah Tangga :

Dipidana dengan pidana penjara paling lama 3 tahun atau denda paling banyak Rp 15.000.000 Lima belas juta rupiah setiap orang

Perlu diketahui bahwa tidak semua kasus kekerasan dalam rumah tangga yang mana perempuan sebagai korban selesai sampai pada tahap pengadilan. Dari setiap kasus yang masuk hampir semua kasus tidak dilimpahkan ke Kejaksaan. Data tersebut dapat dilihat dalam table berikut :

Tabel 4. Data Kasus Yang Dilimpahkan Ke Kejaksaan Dan Tidak Dilimpahkan

\begin{tabular}{|c|c|c|}
\hline Tahun & $\begin{array}{c}\text { Dilimpahkan Ke } \\
\text { Kejakasaan }\end{array}$ & $\begin{array}{c}\text { Tidak Dilimpahkan } \\
\text { Kekejaksaan }\end{array}$ \\
\hline 2016 & 1 & 12 \\
\hline 2017 & - & 8 \\
\hline 2018 & - & - \\
\hline Jumlah & 1 & 20 \\
\hline
\end{tabular}

Sumber UPPA Polres Pohuwato 2018

Berdasarkan data diatas dapat diketahui bahwa sejak tahun 2016 sampai dengan 2018 kasus yang dilimpahkan ke kejaksaan hanyalah satu kasus. Berdasarkan wawancara penulis dengan ibu Siska Zein Saman anggota Unit Pelayanan Perempuan dan Anak (wawancara tanggal 25 Oktober 2018) bahwa :

"Rata-rata kasus yang tidak dilimpahkan ke kejaksaan telah diselesaikan secara musyawarah mufakat Antara pelaku, korban, Anggota Unit PPA Polres Pohuwato dan melibatkan pula P2TP2A sebagai pihak yang terlibat dalam mediasi. Selain dari musyawarah ada pula korban yang menarik laporan polisi karena telah berdamai dengan pelaku." 


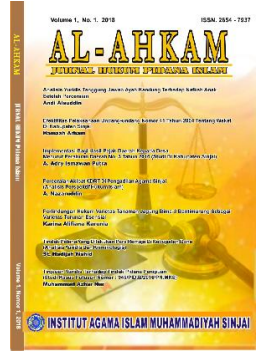

Berdasarkan hasil penelitian penulis bahwa laporan yang sering diterima di UPPA Polres Pohuwato ada beberapa penyebab terjadinya KDRT dapat digolongkan menjadi 2 (dua) faktor, yaitu faktor Internal dan faktor eksternal.

a. Faktor Internal menyangkut kepribadian dari pelaku kekerasan yang menyebabkan ia mudah sekali melakukan tindak kekerasan bila menghadapi situasi yang menimbulkan kemarahan atau frustasi.

b. Faktor Eksternal adalah faktor-faktor di luar diri si pelaku kekerasan. Mereka yang tidak tergolong memilki tingkah laku agresif dapat melakukan tindak kekerasan bila berhadapan dengan situasi yang menimbulkan frustasi misalnya kesulitan ekonomi yang berkepanjangan, factor minuman keras, dan kecemburuan dan penyelewengan istri.

Dari factor diatas mengenai minuman keras seringkali menjadi penyebab kekerasan yang dilakukan oleh suami. Suami yang pulang kerumah dalam keadaan mabuk tentunya memliki emosi yang tidak stabil akibat pengaruh miras. Suami yang mabuk dan ditambah dengan masalah keluarga menyebabkn mudahnya terjadi perlakuan kekerasan oleh suami kepada istri.

Faktor mudah cemburu yang dimiliki baik oleh suami dan seorang istri yang merasa tertekan oleh tindakan suaminya yang sangat membatasi kegiatan istrinya dalam aktualisasi diri, memaksakan istrinya untuk menuruti semua keinginan suaminya. Faktor tersebut mudah memicu adanya pertengkaran di dalam rumah tangga sehingga berakibat kepada kekerasan dalam rumah tangga baik yang dilakukan oleh suami maupun isteri.

Factor ekonomi biasanya disebabkan oleh kebutuhan yang sangat banyak namun tidak sebanding dengan pendapatan dari kepala keluarga. Apalagi ditambah dengan gaya hidup dari keluarga tersebut. Hal ini menyebabkan mudahnya terjadi pertengkaran yang berujung kepada kekerasan kepada istri jadi dapat juga dikatakan peran seorang istri memang sangat besar dalam terjadinya tindak kekerasan dikarenakan istri yang menuntut lebih dari suaminya sedangkan suaminya hanya berpenghasilan pas-pasan.

Factor penyelewengan istri atau terdapat istri yang selingkuh juga menjadi penyebab terjadinya kekerasan dalam rumah tangga. Penyelewengan istri dapat disebabkan oleh ketidakharmonisan dalam rumah tangga.

Dapat diketahui dari beberapa factor diatas bahwa kekerasan terhadap istri bukan saja disebabkan oleh suami sebagai pelaku kekerasan tetapi juga dapat dipicu oleh istri yang melakukan hal - hal yang dapat merusak keutuhan rumah tangganya sendiri.

\section{Simpulan}

Adapun kesimpulan penelitian ini adalah

1. Upaya yang dilakukan oleh Unit Pelayanan Perempuan dan Anak Polres Pohuwato dalam menangani kasus kekerasan terhadap perempuan dalam rumah tangga di wilayah hukum Polres Pohuwato yaitu :

- Tindakan awal yang dilakukan UPPA Polres Pohuwato saat ada aduan atau laporan kasus KDRT yakni membuat aduan atau Laporan Polisi, menyerahkan Surat Tanda Terima Laporan Polisi, membuat Visum Et Repertum, Melakukaan Pemeriksaan Awal.

- Melakukan pemeriksaan dalam Ruang Pelayanan Khusus (RPK)

- UPPA Polres Pohuwato menyediakan Pekerja Sosial (Peksos) 


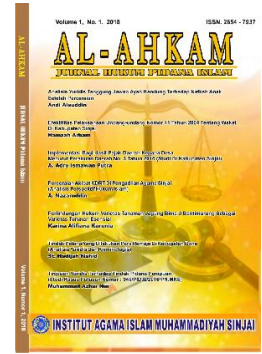

- Menyediakan pemeriksaan kesehatan dalam hal ini korban KDRT dilakukan pemeriksaan oleh Tim Medis apabila terjadi kekerasan secara fisik

- Mengembangkan kerja sama dengan P2TP2A

2. Faktor - faktor yang menjadi penyebab terjadinya kasus kekerasan terhadap perempuan dalam rumah tangga di wilayah hukum Polres Pohuwato:

- Faktor Internal menyangkut kepribadian dari pelaku

- Faktor Eksternal adalah faktor-faktor di luar diri si pelaku kekerasan.

Peneltian ini memberikan rekomendasi perlunya peran penting lembaga-lembaga yang berwenang dalam penanganan tindak pidana kekerasan dalam rumah tangga, harus ditingkatkan agar selalu memberikan pendampingan, dan bantuan bagi pihak-pihak yang terlibat dalam kasus tindak pidana kekerasan dalam rumah tangga selain itu kepada pemerintah agar lebih meningkatkan lagi sosialisasi tentang UU PKDRT sehingga menumbuhkan kesadaran masyarakat serta dapat menurunkan angka kekerasan dalam rumah tangga.

\section{Daftar Pustaka}

Abdul. W \& Mohammad. I, (2001). Perlindungan Terhadap Korban Kekerasaan Seksual, Bandung : Refika Aditama.

Aroma E..M ,(2003), Perempuan Kekerasan dan Hukum,Yogyakarta :UII Press..

Achmad C. (2000). Menggugat Harmoni, Jogjakarta : Rifka Annisa.

Barda N.A, (1998), Beberapa Perempuan, Kekerasan, dan Hukum Aspek Kebijakan Penegakan dan Pengembangan Hukum Pidana, Bandung:Citra Aditya Bakti.

Bambang. W. (2002). Penelitian Hukum Dalam Praktek, Jakarta : Sinar Grafika.

Kalyanamitra,(1999), Menghadapi Kekerasan Dalam Rumah Tangga, Jakarta:Pusat Komunikasi dan Informasi Perempuan.

Rita S.K,(2000), Kekerasan Terhadap Perempuan Dalam Rumah Tangga Sebagai Pelanggaran Hak Asasi Manusia, "Pemahaman Tindak Kekerasan Terhadap Perempuan dan Alternatif Pemecahannya", Jakarta: P.T. ALUMNI,

Thomas. S.(2002), Teori-Teori Kekerasan, Jakarta: Ghalia Indonesia

Trisno. Y,(1994), Kamus Lengkap Bahasa Indonesia Praktis, Surabaya:Arkola.

Wirjono. P, (2003). Asas - Asas Hukum Pidana di Indonesia, Bandung : Refika Aditama.

Kristi. P, (1999). Fakta dan ironi. Jakarta : Jurnal Perempuan.

Harkristuti Harkrisnowo Jurnal Hukum Volume 14 Volume 7 Agustus 2000/ Hukum Pidana dan Perspektif Kekerasan terhadap Perempuan Indonesia, diakses dari https://media.neliti.com/media/publications/83370-none-771195ff.pdf

\section{Undang - Undang dan Peraturan}

Kitab Undang - Undang Hukum Pidana

Undang - Undang RI Nomor 8 Tahun 1981 Tentang Hukum Acara Pidana

Undang - Undang RI Nomor 23 Tahun 2004 Tentang Penghapusan Kekerasan Dalam Rumah Tangga

Undang - Undang RI Nomor 2 Tahun 2002 Tentang Kepolisian RI

Keputusan Presiden Nomor 70 Tahun 2002 Tentang Organisasi dan Tata Kerja Kepolisian Negara Republik Indonesia

Keputusan Kapolri No. Pol. : Kep/53/X/2002 tanggal 17 Oktober 2002 tentang Organisasi dan Tata Kerja Satuan-Satuan Organisasi pada Tingkat Markas Besar Kepolisian Negara Republik Indonesia, beserta perubahannya 


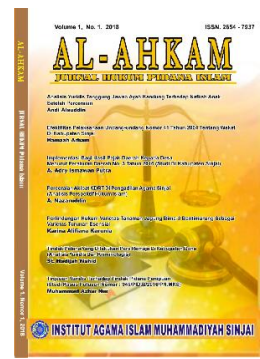

\section{Al-Ahkam}

Jurmal Hukum Pidana Islam

Volume 2, No. 1, 2020

ISSN (print) : 2654-7937

ISSN (online) : 2715-0313

Homepage : http://journal.iaimsinjai.ac.id/index.php/al-ahkam/index

Keputusan Kapolri No. Pol. : Kep/54/X/2002 tanggal 17 Oktober 2002 tentang Organisasi dan Tata Kerja Satuan-Satuan Organisasi pada Tingkat Kepolisian Negara Republik Indonesia Daerah (Polda), beserta perubahannya. 